\title{
Taxation and Budget Reform Commission (TBRC) Constitutional Amendment 3: Changes and Improvements Not Affecting the Assessed Value of Residential Real Property 1
}

Rodney L. Clouser²

A series of 16 fact sheets has been written on statutory and constitutional proposals adopted by the Taxation and Budget Reform Commission (TBRC). The publications in this series can be accessed at http://edis.ifas.ufl.edu. Fact sheets FE733 through FE741 address statutory changes and fact sheets FE742 through FE748 address constitutional amendments. These fact sheets should not be considered as an all-inclusive assessment of the statutory or constitutional changes recommended by the Taxation and Budget Reform Commission. Some details of proposed changes may not have been discussed due to space limitations. These fact sheets are not intended as a replacement for personal knowledge about actual or proposed changes but are a guide to inform the public on the issues.

\section{Introduction}

According to Article XI, Section 6 of the Florida Constitution, "Beginning in 2007 and each twentieth year thereafter there shall be established a taxation and budget reform commission." The Taxation and
Budget Reform Commission (TBRC) is charged with the following:

examine the state budgetary process, the revenue needs and expenditure processes of the state, the appropriateness of the tax structure of the state, and governmental productivity and efficiency; review policy as it relates to the ability of state and local government to tax and adequately fund governmental operations and capital facilities required to meet the state's needs during the next twenty-year period; determine methods favored by the citizens of the state to fund the needs of the state, including alternative methods for raising sufficient revenues for the needs of the state; determine measures that could be instituted to effectively gather funds from existing tax sources; examine constitutional limitations on taxation and expenditures at the state and local level; and review the state's comprehensive planning, budgeting and needs assessment processes to

1. This is EDIS document FE742, a publication of the Food and Resource Economics Department, Florida Cooperative Extension Service, Institute of Food and Agricultural Sciences, University of Florida, Gainesville, FL. Published July 2008. Please visit the EDIS website at http://edis.ifas.ufl.edu.

2. Rodney L. Clouser, professor and extension public policy specialist of the Food and Resource Economics Department, Florida Cooperative Extension Service, Institute of Food and Agricultural Sciences, University of Florida, Gainesville, FL.

The Institute of Food and Agricultural Sciences (IFAS) is an Equal Opportunity Institution authorized to provide research, educational information and other services only to individuals and institutions that function with non-discrimination with respect to race, creed, color, religion, age, disability, sex, sexual orientation, marital status, national origin, political opinions or affiliations. U.S. Department of Agriculture, Cooperative Extension Service, University of Florida, IFAS, Florida A. \& M. University Cooperative Extension Program, and Boards of County Commissioners Cooperating. Larry Arrington, Dean 


\section{determine whether the resulting information adequately supports a strategic decision-making process.}

The TBRC can make statutory recommendations to the Florida Legislature and directly place proposed constitutional amendments on the ballot for approval or rejection by Florida voters.

Fact sheets in this series will present information on constitutional amendments the TBRC has placed on the fall 2008 general election (2008 November presidential election) ballot. The commission was charged with holding public meetings to carry out their responsibilities and has been meeting since March of 2007. The committee concluded their work and transmitted their proposed constitutional amendments to the Florida Secretary of State on April 28,2008 . All the proposed constitutional amendments required an affirmative vote of at least two-thirds of the voting members of the commission (17 members). In total, the TBRC approved eleven constitutional proposals. The committee combined these eleven proposals into seven constitutional amendments. The amendments passed by the TBRC will be numbered Amendments 3 through 9 on the fall ballot (Amendments 1 and 2 are reserved for two other 2008 amendment proposals, one approved by the legislature and the other a citizen initiative).

The TBRC amendments placed on the 2008 general election ballot are listed by ballot title below:

- Amendment 3: Changes and Improvements Not Affecting the Assessed Value of Residential Real Property

- Amendment 4: Property Tax Exemption of Perpetually Conserved Land; Classification and Assessment of Land Used for Conservation

- Amendment 5: Eliminating State Required School Property Tax and Replacing with Equivalent State Revenues to Fund Education

- Amendment 6: Assessment of Working Waterfront Property Based upon Current Use

- Amendment 7: Religious Freedom
- Amendment 8: Local Option Community College Funding

- Amendment 9: Requiring 65 Percent of School Funding for Classroom Instruction; State's Duty for Children's Education

Each fact sheet in this series will provide details regarding one of the amendments, submitted to the Secretary of State, in the order they will appear on the ballot (Amendment 3, Amendment 4, Amendment 5, Amendment 6, Amendment 7, Amendment 8, and Amendment 9).

\section{Proposed Amendment 3}

When people go to their polling places in November 2008, they will see information on the amendment, references to the portion of the constitution that will be altered, sponsor of the amendment, the ballot title, and the ballot summary. The information for Amendment 3 will be similar or identical to the following and the ballot title and ballot summary are direct quotes:

Proposed Constitutional Amendment No. 3: ARTICLE VII, SECTIONS 3 AND 4; ARTICLE XII, NEW SECTION (Taxation and Budget Reform Commission)

Ballot Title: CHANGES AND IMPROVEMENTS NOT AFFECTING THE ASSESSED VALUE OF RESIDENTIAL REAL PROPERTY

Ballot Summary: Authorizes the legislature, by general law, to prohibit consideration of changes or improvements to residential real property which increase resistance to wind damage and installation of renewable energy source devices as factors in assessing the property's value for ad valorem taxation purposes. Effective upon adoption, repeals the existing renewable energy source device exemption no longer in effect.

\section{Effect of Amendment 3}

The proposed amendment repeals the current renewable energy source property tax exemption effective immediately if the amendment is passed by 
the voters. The remainder of the amendment becomes effective on January 1, 2009, if approved.

The constitutional proposal amends Article VII, Section 4 with the following language:

5(h) The legislature, by general law and subject to conditions specified therein, may prohibit the consideration of the following in the determination of the assessed value of real property used for residential purposes: (1) Any change or improvement made for the purpose of improving the property's resistance to wind damage, and (2) The installation of a renewable energy source device.

The language reinstates the renewable energy source device and adds improvements related to resisting wind damage from use as determinants of assessed value of residential real property. It should be noted the language indicates the legislature "may prohibit" the use of these items in determining assessed value but does not use stronger language of "shall prohibit."

The TBRC also made a companion statutory recommendation and forwarded it to the legislature that would implement the constitutional amendment. The proposed statute defines "resistance to wind damage" devices not to be considered in determining assessed value of real residential property.

\section{Impact of Amendment 3}

Since the proposed constitutional amendment deals with exemptions to property taxes for renewable energy and wind resistant devices, its impact will be on local units of government (counties, municipalities, schools, etc.) and not on state government revenues. As the proposed amendment would not take effect until January 1, 2009 , it will not affect local government revenues until fiscal year 2009-2010 (typically October 1, 2009-September 30, 2010).

The fiscal impact on local units of government has been estimated at $\$ 11.4$ million between fiscal years 2009-2010 and 2011-2012. Unless local governments raised millage rates (tax rates per $\$ 1000$ of assessed value) to offset the decrease in assessed value that would occur, the amount of taxes collected over this three-year period would be $\$ 11.4$ million less compared to current law.

Some people contend that passage of both the statutory and constitutional change would be an incentive for residential property owners to retrofit homes with these devices. This may also result in less damage from hurricanes and strong winds to these properties. Addition of these devices to residential properties, if they do reduce damage from storms, could dampen future increases in residential property insurance rates. Likewise, installing energy saving devices could make residential property more energy efficient and reduce energy costs to residential homeowners.

Staff analysis indicates both the statutory and constitutionally proposed change applies to a broad range of residential property types, including rental homes and apartments, multiple homes owned by a single owner, vacation homes, and homesteaded property. Less local government revenue anticipated from the proposed change will most likely be a concern to local units of government, especially after revenue decreases because of the property tax amendment that passed in January of 2008. Local governments are concerned about the quantity and quality of local services they can provide with a more restricted revenue base.

\section{Summary}

Adoption of the constitutional amendment requires a vote in favor of the amendment by a minimum of $60 \%$ of those voting. Additionally, amendments are subject to legal challenges and could possibly be removed from the ballot if successfully challenged.

Voters in Florida have the opportunity to change the state constitution during the 2008 general election. The intent and purpose of the information contained in this fact sheet on Amendment No. 3 is not to tell individuals how to vote. Rather, the fact sheet is provided to help voters become more informed. Informed voters need to be more knowledgeable of the ballot issue on which they are voting than just by reading a ballot title and ballot 
summary. Ballot titles and summaries do not inform voters in significant detail, nor do they inform voters on policy implications of what a yes or no vote implies. Because informed voters make informed public policy decisions, your challenge as a voter and a citizen is to become informed and then, by casting your ballot, make your values and preferences known.

\section{References}

Florida Department of State, Division of Elections. 2008. Initiatives / Amendments / Revisions. Division of Elections, Flordia Department of State, Tallahassee, FL (May).

http://election.dos.state.fl.us/initiatives/ initiativelist.asp

Florida Taxation and Budget Reform Commission. 2008. A resolution proposing an amendment to Sections 3 and 4 of Article VII and the creation of a new section in Article XII of the State Constitution. TBRC, Tallahassee, FL (May). http://www.floridatbrc.org/pdf/CP4E2Final2.pdf

Florida Taxation and Budget Reform Commission. 2008. Staff Analysis and Economic Impact Statement. TBRC, Tallahassee, FL (May). http://www.floridatbrc.org/pdf/ 3_28_08SDCS_CP0004FirstEngrossedStaffAnalysis. pdf

Florida Taxation and Budget Reform Commission. 2008. Transmittal letter. TBRC, Tallhassee, FL. http://www.floridatbrc.org/pdf/ CPTransmittalLetter.pdf

\section{Resources}

Clouser, Rodney L. 2008. Taxation and Budget Reform Commission (TBRC) Statutory Recommendation: Residential Property Assessment for Storm Hardening Improvements and Installation of Renewable Energy Source Devices. Electronic Data Information Source FE734. Food and Resource Economics Department, University of Florida, Gainesville, FL. http://edis.ifas.ufl.edu/FE734. 